DOI: $10.1515 / \mathrm{rpp}-2017-0003$

Doctor of Pedagogical Sciences, Associate Professor, VICTOR MOZGOVYI Mykolaiv Affiliated Branch of Kyiv National University of Culture and Arts Address: 17 Dekabrystiv St., Mykolaiv, 54017, Ukraine E-mail: viktoriya-72@mail.ru

\title{
THE DIRECTIONAL SPECTRUM OF PEDAGOGICAL ACTION IN THE CONTEXT OF FOREIGN SCHOLARS' VIEWS
}

\begin{abstract}
The article deals with the study of crucial features and functions of the direction of pedagogical action in educational practices of Ukraine and the Russian Federation. Using the descriptional characteristics presented by scientists and pedagogues-scholars from the mentioned countries we have defined common and distinct features of the phenomenon under study, compared its structure and components. The analyzed definitions suggest that the direction of pedagogical action is based on the synthesis of theatrical and pedagogical art. The direction of pedagogical action is oriented toward methodical provision of modern trends in the development of humanistic education and creates relevant emotional field for the comprehensive development of personality. As a result, we have found out that the direction of pedagogical action in the Russian Federation is practice-oriented and is used as a method of emotional influence on pupil while solving educational tasks of a comprehensive secondary school. More common is the spectrum of using the direction of pedagogical action in the national systems of secondary and higher education where this phenomenon is mostly associated with the development of teacher professionalism, their pedagogical mastery that contributes to the organization of the educational process at a new level $-a$ creative function that is oriented toward the establishment of efficient pedagogical interaction. Based on the results of the comparative analysis, we have concluded that comprehending the efficiency of using the direction of pedagogical action in the systems of secondary and higher education in Ukraine and the Russian Federation will contribute to a new level of organization of free pedagogical interaction where the author's position of teachers may surely help to meet personal educational needs of their pupils and students.

Key words: phenomenon, direction of pedagogical actions, pedagogical interaction, synthesis of theatrical and pedagogical art, creative function, freedom of personality.

\section{INTRODUCTION}

Progressive changes that took place in the national systems of secondary and higher education ("The 2015 Law on Higher Education", "The 2016 Concept of the New Ukrainain School") give promise for the mentioned educational fields not only to be updated but also recognized at the international level. European education systems have oriented Ukraine toward such priority directions as autonomy of a higher education institution, academic mobility, academic freedom, pedagogical partnership, etc. The realization of the mentioned strategic tasks needs, first of all, readiness of teachers and instructors for pedagogical action based on radically new principles, namely, a free cultural, professional interaction with all the participants of the educational process. Perspective pedagogy of partnership may be successful provided personal freedom of both pupils and teachers is taken into account. To implement such a programme a modern teacher should be ready to realize a new function of pedagogical interaction - the direction of pedagogical action.
\end{abstract}




\section{THE AIM OF THE STUDY}

Taking into account the connection between the direction of pedagogical action with certain pedagogical notions and terms, the aim of our study is to conduct the comparative analysis of the phenomenon in the context of Ukrainian and Russian education systems.

\section{THEORETICAL FRAMEWORK AND RESEARCH METHODS}

Analysing the origin and development of the phenomenon "the direction of pedagogical action", one should pay attention to the native and foreign scholars' studies of the development of future teachers' ability to direct pedagogical interaction at different stages of their professional activity (S. Boyd, O. Bulatova, L. Dubyna, V. Kan-Kalyk, B. Kessler, O. Kniaziev, G. Koch, Ye. Kopulets, L. Kramushchenko, O. Lavrinenko, L. Lymarenko, O. Otych, M. Schewe, S. Shvydka, V. Zahviazynskyi, O. Zadorina, I. Ziaziun and others) as well as scientific-methodic justification of the direction of a lesson (V. Bukatov, O. Yershova and others).

The main methods we have used in our study are description, comparison and generalization that are typical for methodology of comparative pedagogy.

\section{RESULTS}

Modern pedagogical practice at different levels of scientific justification is often viewed as the art of pedagogical interaction. This suggestion can be proved by the fact that humanistic and creative principles dominate in modern professional education. The priority of anthropocentrism in modern society development will surely prefer those ways where personality with their impressions, thoughts, positions, beliefs, culture, erudition takes first place. The most common form of understanding the pedagogical interaction organization is the synthesis of theatrical and pedagogical practice. It should be mentioned that pedagogical theory includes a scientific approach that regulates inner and outer factors of the mentioned synthesis, i.e. a drama-based hermeneutic approach. Expressiveness and efficiency of such an approach have ensured its vast popularity in many education systems around the world. In certain pedagogical practices (Germany, France, Great Britain, etc.) it still remains the synthesis of theatrical art and pedagogy having formed an alternative methodology, namely, drama-based pedagogy, that can be proved by the conducted analysis of foreign scholars' works (Boyd, Schewe, 2012; Kessler, Küppers, 2008; Koch, 2011).

In Ukrainian and Russian pedagogical practice, however, the mentioned approach has transformed into hermeneutic pedagogy with the forming of a new artistic pedagogical function - the direction of pedagogical action. The defined fact can be easily explained: theatrical pedagogy formed as a practical component of actor training at the end of the $19^{\text {th }}$ century in the Russian Federation. In addition, a long period of the historical development in both countries involved geographical, political and ideological co-existence that certainly influenced education. After becoming independent in 1991 Ukraine simultaneously acquired the right of authorship on original ideas and concepts in pedagogy.

Further exposition of main results requires that the essence of the comparative analysis is determined and the main demands for its conducting in the context of pedagogical research are adhered. Justifying the methods of pedagogical research, S. Honcharenko indicates that "the method used for comparing the studied objects and determining their similarities and differences is called "comparison" (Гончаренко, 2008). Explaining the essence of the notion "comparison" O. Novikov emphasizes that "comparison always includes analysis as it is necessary to single out relevant features of comparison. Comparison is one of theoretical methods-operations that are inherent in any activity" (Новиков, 2013).

Taking into account the abovementioned recommendations, we have defined relevant features in order to study them in the suggested scientific positions regarding the 
direction of pedagogical action as a method or representation of the phenomenon as a function that corresponds to a certain level of professional training - pedagogical mastery.

First of all, we would like to start our analysis of the phenomenon based on the achievements of native scholars. I. Ziaziun was first who openly stated about the expediency of teachers' mastering acting and directing skills. In his work "Pedagogical Mastery" the scholar indicated that "the direction of pedagogical action is viewed as teacher's ability to construct and build micro situations of interaction with pupil (or pupils) according to a task and logic of a pedagogical idea" (Зязюн, Крамущенко, Кривонос, 2008). However, more general is the scholar's definition of pedagogical direction presented in his monograph "Philosophy of Pedagogical Action" where the author emphasizes the fact that "being directors teachers perform such functions as analysis, goal-setting, planning, organization, design, motivation, evaluation, communication, etc. (Зязюн, 2008).

One should also pay attention to the works of those native scholars who investigated pedagogical achievements of the founders of Ukrainian pedagogy. Thus, analyzing A. Makarenko's pedagogical heritage in the context of mastery of the pedagogical action direction, L. Kramushchenko concludes that "art of building the logic of teacher's activity presupposes a certain sequence of different situations, namely, mise en scene, that ensures solving pedagogical tasks and is defined by the notion "the direction of pedagogical interaction" (Крамущенко, 2008). Studying the prominent personalities in pedagogical theory and practice, L. Dubyna distinguishes V. Sukhomlynskyi's pedagogical talent and indicates that "a high level of mastering both strategy and tactics of pedagogical interaction as well as acting and directing skills allow to consider him not only the outstanding scholarhumanist but also director of pedagogical action" (Дубина, 2001).

As for modern researchers on the phenomenon, it should be mentioned that certain scholars view the direction of pedagogical action as an artistic and pedagogical function of professional interaction between teacher and partcipants of the educational process. Thus, justifying the foundations of forming art and culture teachers' pedagogical mastery, L. Lymarenko concludes that "using the art of theatre in the educational process art and culture teachers play several roles: they are playwrights as they organize their lessons in accordance with the laws of drama, directors as they follow the laws of direction and actors as they use the art of stage action" (Лимаренко, 2006).

Taking into account the previous positions regarding the essence of pedagogical action direction, the author of this paper has his own interpretation that characterizes the phenomenon according to teacher's creative function directed at ensuring the efficiency of pedagogical interaction within the realization of tasks that occur during the educational process.

In our opinion, quite interesting are the achievements of Russian scholars. For instance, O. Yershova studied pedagogy as practical direction and stated that "no matter the state a class may be in at the beginning of the lesson, teachers must always know how to communicate with pupils, ease the tension between them, quickly evaluate the situation in the class and correct not only the lesson plan but also their own behaviour as it should be expressive and proper for the pupils as well as encourage them to work. In other words, teachers have to direct their lessons in accordance with new concrete conditions" (Ершова, Букатов, 2010).

Of scientific interest is also the interpretation of the essence of "pedagogical direction" presented by O. Bulatova. The author states that "the direction (pedagogical) means planning a lesson as a detailed score: skillful logic design of the interaction between the participants of the educational process; the ability to encourage valuable attitude towards the object of the study; organization of moral influence on pupils; selection of main 
influential episodes of the lesson, their production; inner combination of all the shades of the lesson, all the kaleidoscope of events, all the spectrum of expressed feelings; planning and organization of pace and rhythm of the lesson; revelation of central moments of the lesson in the space-time continuum (Булатова, 2001).

Quite practice-oriented is O. Kniaziev's approach as it justifies direction and management of edutainment technologies. Characterizing these, the author states that "under such direction one means the activity that is oriented toward the production of edutainment technologies as while realizing them teacher is responsibile for organization, content building, using the playing techniques (Князев, Одинцова, 2008).

In the context of the abovementioned views, the most profound definition of "pedagogical action direction" is given in "The Pedagogical Dictionary" edited by V. Ziahviazynskyi. The scholar views pedagogical direction as "the activity of the teacher, who has considerable humanistic and pedagogical potential, is directed at development and implementation of the idea of the lesson, that includes forming pupils' integrated notions and relatively complete means of activity; pedagogically justified structure of the lesson with singling out the main influential emotional episodes; defining logic of the interaction between the participants of the educational process, conditions for expressing relevant feelings in these situations, content and emotional dominants of the interaction, conditions favourable for encouraging valuable attitude towards the object of the study; organization of moral influence on pupils; planning and organization of the pace-rhythm image of the interaction, revelation of central moments during the lesson (meeting, presentation) in time and space of pedagogical mise en scene; search for the variants of using different verbal and non-verbal languages for expressing thoughts and feelings that reveal the significance of the fragment of education content; motivation towards common creative search, positive mood, at most favourable conditions for children's intellectual activity" (Зягвязинский, 2008).

Comparing scientific approaches to the essence and functionality of pedagogical action direction in Ukraine and the Russian Federation, we can make relevant generalization of the defined features of the phenomenon. Thus, along with the notion of pedagogical action direction native scholars use the notion of pedagogical mastery that actively uses the synthesis of theatrical and pedagogical art in forming theoretical and practical foundations for the realization of effiicient pedagogical action/interaction. Such an approach has widened the direction of pedagogical action in the context of scientific and pedagogical development, namely, the creative artistic and pedagogical function with relevant structure and components. We cannot state that we have presented "panacea" to solve the main problem of the educational process - to overcome personality (child, pupil, student) resistance to the process of learning/upbringing. However, in the context of the realization of the approaches to freedom of personality development in modern education space the defined function may be considered as one of the variants to improve the approaches to the organization of pedagogical action based on democratic principles that are recognized by the international pedagogical community. The expediency of such activity can be proved by "The 2016 Concept of the New Ukrainian School" where the majority of presented key components concern the creation of subject-subject interaction within comprehensive secondary schools. As for the positions of Russian pedagogues-researchers, we can state about the clearly defined practical vector of pedagogical action dicrection. We do not underestimate the significance of this scientific achievement, but its practical orientation (lesson direction, emotional richness of single stages of the lesson, educational events, etc.) fundamentally limits functionality of the studied phenomenon in the context of development of pedagogical theory and practice humanization. 


\section{CONCLUSIONS}

So, the conducted comparative analysis of the phenomenon "the direction of pedagogical action" in Ukrainian and Russian education systems has allowed to single out common and distinct features in its interpretation. The obtained results suggest that the direction of pedagogical action is mostly associated with comprehensive secondary education of the mentioned countries, namely, the functionality of the studied phenomenon is connected with the creation of relevant emotional background (adjustment, infusion, etc.) during the organization of learning/upbringing. At the same time, comprehending the efficiency of using the direction of pedagogical action in the systems of secondary and higher education in Ukraine and the Russian Federation will contribute to a new level of organization of free pedagogical interaction where the author's position of teachers may surely help to meet personal educational needs of their pupils and students.

Perspectives of further researches have oriented us toward comparing the approaches to future teachers' training for the direction of pedagogical action in Ukraine and European experience in training future drama teachers.

\section{REFERENCES}

1. Boyd, S., Schewe, M. (2012). Welttheater: Übersetzen, Adaptieren, Inszenieren [World Theatre: Translation, Adaptation, Production]. Berlin : Schibri-Verlag, 184 p. (in German).

2. Kessler, B., Küppers, A. (2008). Dramapädagogik, interkulturelle Kompetenz und holistisches Fremdsprachenlernen [Theatre Pedagogy, Intercultural Competece and Intergrated Learning of Foreign Languages]. Scenario, Volume 5, Issue 2, pp. 3-24 (in German).

3. Koch, G. (2011). Zur Theaterpädagogik in der Bundesrepublik Deutschland. Ein Überblick [Theatre Pedagogy in the Federal Republic of Germany. A Overview]. Scenario, Volume 5, Issue 1, pp. 76-94 (in German).

4. Булатова, О. С. (2001). Педагогический артистизм : учеб. пособ. для студ. выст. пед. учеб. заведений [Pedagogical Artistry: Tutorial for Students of Higher Education Pedagogical Institutions]. М. : Академия, 240 p. (in Russian).

5. Гончаренко, С. У. (2008). Педагогічні дослідження : методологічні поради молодим науковиям [Pedagogical Researches: Methodological Advice for Young Scholars]. K.; Вінниця : ДОВ “Вінниця”, 278 р. (in Ukrainian).

6. Дубина, Л. (2001). Сухомлинський В. О. як режисер педагогічної дії [Sukhomlynskyi V. O. as a Director of Pedagogical Action]. Педагогіка $і$ психологія професійної освіти [Pedagogy and Psychology of Professional Education], No 3, pp. 155-164 (in Ukrainian).

7. Ершова, А. П., Букатов, В. М. (2010). Режиссура урока, общение и поведение учителя: пособие для учителя [The Direction of Lesson, Communication and Behaviour of Teacher]. М. : Флинта, 344 p. (in Russian).

8. Зягвязинский, В. И. (2008). Педагогический словарь : учеб. пособ. [Pedagogical Dictionary: Tutorial]. М. : Академия, 345 p. (in Russian).

9. Зязюн, І. А., Крамущенко, Л. В., Кривонос, І. Ф. (2008). Педагогічна майстерність : підручник [Pedagogical Mastery: Textbook]. К. : СПД Богданова А. М., 376 p. (in Ukrainian).

10. Зязюн, І. А. (2008). Філософія педагогічної дії : монографія [Philosophy of Pedagogical Action: Monograph]. Черкаси : ЧНУ імені Богдана Хмельницького, 608 p. (in Ukrainian). 
11. Князев, А. М., Одинцова, И. В. (2008). Режиссура и менеджмент технологий активно-игрового обучения : учеб. пособие [Direction and Management of Edutaiment Technologies: Tutorial]. М. : РАГC, 207 p. (in Russian).

12. Крамущенко, Л. В. (2008). Майстерність режисури педагогічної взаємодії у досвіді А. С. Макаренка [Mastery of the Direction of Pedagogical Action in A. Makarenko's Experience]. Rerieved 15.01.2017 from : Ipnpu.edu.ua / nauka / Vitoki / 2008 _vutoku_5 / kramuchtenko.pdf.

13. Лимаренко, Л. I. (2006). Вid театру до майстерності (формування педагогічної майстерності учителів художньої культури на прикладі вивчення циклу театральних дисииплін) : монографія [From Theatre to Mastery (Forming Art and Culture Teachers' Pedagogical Mastery on the Example of Studying Theatrical Disciplines): Monograph]. Херсон : Видавництво ХДУ, 116 p. (in Ukrainian).

14. Новиков, А. М., Новиков, Д. А. (2013). Методология : словарь системы основных понятий [Methodology: the Dictionary of the Main Concepts System]. М. : Либриком, 208 p. (in Russian). 